\title{
MANAJEMEN PENGAWASAN KEPALA MADRASAH DAN KINERJA GURU DALAM MENINGKATKAN SIKAP RELIGIUSITAS PESERTA DIDIK
}

\author{
Ahmad Jaelani \\ Program Pascasarjana UIN Sunan Gunung Djati Bandung, Jawa Barat Indonesia \\ e-mail: ahmadjaelani1919@gmail.com
}

\begin{abstract}
Religiosity attitude of students so far has not received enough attention in an educational institution. Educators or teachers are still preoccupied with various administrative tasks so that the performance of teachers as educators who are supposed to provide education to students is neglected. Especially religious education which provides a change in the attitude of religiosity of students. Religiosity attitude of students is still low. Allegedly because the performance of teachers and madrasah head supervision is not optimal. This study aims to determine the supervision management of madrasa principals and teacher performance in improving the religiosity of students in Madrasah Aliyah Darul Ulum Sukaraja, Garut Regency. The study uses a qualitative approach with primary data obtained from observations and interview results. The results obtained were the supervision of the madrasa headmaster and the teacher's performance carried out well, optimally and effectively so that the students' religiosity attitude increased. These findings reinforce the opinion of Komariah and Mulyati (2009) in Encu (2012: 9) that good and effective supervision is obtained from four aspects, namely: (1) setting performance standards, 2) measuring performance, 3) comparing performance with predetermined standards, 4) take corrective action when a deviation is detected. While the indicators of supervision carried out by a leader in this case are the headmaster of a madrasa, namely: a) setting targets and limits of work, b) defining common goals clearly, c) turning ideas into reality, $d$ ) supervising during program realization.
\end{abstract}

Keywords: madrasah head supervision management, teacher performance, student religiosity

\begin{abstract}
ABSTRAK
Sikap religiusitas peserta didik selama ini masih kurang mendapat perhatian pada sebuah lembaga pendidikan. Pendidik atau guru masih disibukkan dengan berbagai tugas administrasinya sehingga kinerja guru sebagai pendidik yang seharusnya memberikan pendidikan kepada peserta didik menjadi terbengkalai. Terutama pendidikan agama yang memberikan perubahan terhadap sikap religiusitas peserta didik. Sikap religiusitas peserta didik masih rendah. Diduga karena kinerja guru dan pengawasan kepala madrasah yang belum optimal. Penelitian ini bertujuan untuk mengetahui manajemen pengawasan kepala madrasah dan kinerja guru dalam meningkatkan religiusitas peserta didik di Madrasah Aliyah Darul Ulum Sukaraja Kabupaten Garut. Penelitian menggunakan pendekatan kualitatif dengan data primer yang diperoleh dari observasi dan hasil wawancara. Hasil penelitian yang diperoleh
\end{abstract}


adalah manajemen pengawasan kepala madrasah dan kinerja guru dilaksanakan dengan baik, optimal dan efektif sehingga sikap religiusitas peserta didik meningkat. Hasil temuan ini memperkuat pendapat Komariah dan Mulyati (2009) dalam Encu (2012:9) bahwasanya pengawasan yang baik dan efektif itu diperoleh dari empat aspek, yaitu: (1) menetapkan standar kinerja, 2) mengukur kinerja, 3) membandingkan unjuk kinerja dengan standar yang telah ditetapkan, 4) mengambil tindakan korektif saat terdeteksi penyimpangan. Sementara indikator dari pada pengawasan yang dilakukan oleh seorang pemimpin dalam hal ini adala kepala madrasah yaitu: a) menentukan target dan batasan kerja, b) menentukan tujuan bersama dengan jelas, c) mewujudkan gagasan menjadi kenyataan, d) melakukan pengawasan pada saat realisasi program.

Kata Kunci: manajemen pengawasan kepala madrasah, kinerja guru, religiusitas peserta didik

\section{PENDAHULUAN}

Pendidikan sangatlah penting bagi kehidupan masyarakat baik dalam mewujudkan kepentingan pribadinya maupun mewujudkan program pemerintah sesuai yang tercantum dalam tujuan pendidikan nasional yakni mencerdaskan kehidupan berbangsa dan bernegara. Hasil dari pada pendidikan tersebut menjadikan masyarakat memiliki bekal yang cukup untuk menjalani kehidupannya sehari-hari. Dengan bekal pendidikan, masyarakat akan lebih kompeten serta mampu meningkatkan taraf hidupnya yang berkualitas. Selain itu masyarakat akan lebih berkembang dan maju serta mampu bersaing secara kompetitif di era yang penuh persaingan ini, terutama bagi anakanak sebagai generasi umat terbaik yang akan menjunjung tinggi harkat martabat suatu negara dan bangsanya.

Dalam kehidupan yang kompetitif dan penuh persaingan seperti ini, diperlukan sumber daya manusia yang berkualitas dan memiliki kemampuan serta kompetensi yang memadai, yaitu sumber daya manusia yang mampu menghadapi persaingan dan terampil dalam berbagai aktifitas dikehidupannya sehari-hari. Salah satunya adalah seorang pemimpin yang dapat mempengaruhi dan mengarahkan perilaku anggota masyarakatnya ke arah tujuan tertentu. Dengan demikian, pemimpin dianggap mewakili aspirasi masyarakat dan pemimpin dapat memperjuangkan harapan sebagian orang. Selain beberapa faktor yang mendasari lahirnya pemimpin, pada kenyataanya pemimpin mempunyai kecerdasan dan wawasan yang lebih luas dibandingkan dengan rata-rata pengikutnya, sehingga wajar kehadiran pemimpin sangat dirindukan untuk mengatasi berbagai masalah yang dihadapi oleh anggota masyarakat.

Begitupun dalam dunia pendidikan. Sebagai suatu sistem, pendidikan nasioanal haruslah dikelola secara tepat agar tujuan dapat tercapai secara efektif dan efisien, karena itu untuk pengelolaan pendidikan diperlukan administrator yang memiliki kinerja secara optimal dan maksimal guna mewujudkan lulusan-lulusan terbaik yang diharapkan oleh masyarakat. 
Kepala Madrasah sebagai seorang pemimpin merupakan salah satu komponen pendidikan yang paling berperan dalam meningkatkan kualitas pendidikan, seperti yang dikemukakan oleh Supriadi (1998:346) dalam Mulyasa (2013: 24) bahwa:

"Erat hubunganya antara mutu Kepala sekolah dengan berbagai aspek kehidupan sekolah seperti disiplin sekolah, iklim budaya sekolah, dan menurunnya perilaku nakal peserta didik, kepala madrasah bertanggung jawab atas penyelenggaraan kegiatan pendidikan, administrasi sekolah, pembinaan tenaga kependidikan lainnya dan pendayagunaan serta pemeliharaan sarana dan prasarana".

Fungsi utama kepala madrasah sebagai pemimpin pendidikan ialah menciptakan situasi belajar mengajar sehingga guru-guru dapat mengajar dan peserta didik dapat belajar dengan baik. Dalam melaksanakan fungsi tersebut, kepala madrasah memiliki tanggung jawab ganda yaitu melaksanakan administrasi sekolah sehingga tercipta situasi belajar mengajar yang baik, dan melaksanakan supervisi sehingga guru-guru bertambah dalam menjalankan tugas-tugas pengajaran dalam membimbing pertumbuhan peserta didik.

Supervisi pendidikan atau yang lebih dikenal dengan pengawasan pendidikan memiliki konsep dasar yang saling berhubungan meskipun keduanya memiliki perbedaan tertentu. Dalam konsep dasar pengawasan dan supervisi pendidikan dijelaskan beberapa dasar-dasar tentang konsep supervisi pendidikan itu sendiri. Pendidikan berbeda dengan mengajar, pendidikan adalah suatu proses pendewasaan yang dilakukan oleh seorang pendidik kepada peserta didik dengan memberikan stimulus positif yang mencakup kognitif, afektif, dan psikomotorik. Sedangkan pengajaran hanya mencakup kognitif saja artinya pengajaran adalah suatu proses pentransferan ilmu pengetahuan tanpa membentuk sikap dan kreatifitas peserta didik. Oleh karena itu, pendidikan haruslah diawasi atau disupervisi oleh supervisor yang dapat disebut sebagai kepala madrasah dan pengawas-pengawas lain yang ada di departemen pendidikan. Pengawasan disini adalah pengawasan yang bertujuan untuk meningkatkan kinerja para pendidik dan pegawai sekolah lainnya dengan cara memberikan pengarahan-pengarahan yang baik dan bimbingan serta masukan tentang cara atau metode mendidik yang baik dan professional.

Menurut (Supardi, 2014:37) supervisi pembelajaran yang dilakukan kepala madrasah bertujuan meningkatkan mutu proses dan hasil pembelajaran. Mutu proses pembelajaran adalah mutu dari aktifitas pembelajaran yang dilakukan guru dan mutu aktifitas belajar yang dilakukan peserta didik. Sedangkan mutu hasil pembelajaran adalah mutu dari aktifitas pembelajaran yang dilakukan guru dan mutu aktifitas belajar yang dilakukan peserta didik.

Hasil pengamatan yang dilakukan oleh supervisor, tampak sebagian guru belum menunjukkan kinerja baik dalam menjalankan tugas dan fungsinya, artinya sesuai dengan tugas pokok dan fungsi guru, seperti: kegiatan dalam merencanakan program pengajaran, melaksanakan 
kegiatan pembelajaran, melaksanakan program perbaikan dan pengayaan serta mengadakan pengembangan bidang pengajaran yang menjadi tanggung jawabnya. Sebagai gambaran profil guru yang kinerjanya masih rendah, antara lain: guru mengajar secara monoton tanpa adanya persiapan yang matang, guru masih menggunakan persiapan mengajar dengan sangat sederhana, belum sepenuhnya menggunakan acuan kurikulum yang telah ditetapkan, dan tidak konsisten dalam implementasi skenario rencana pelaksanaan pembelajaran yang telah dipersiapkan dan pada proses pembelajaran guru masih menggunakan metode ceramah. Fenomena tersebut teramati pada waktu pelaksanaan kepengawasan di Madrasah Aliyah Darul Ulum Sukaraja Kabupaten Garut. (Sumber: Hasil Wawancara dengan Wakamad. Kurikulum MA Darul Ulum Aa Dadan., S.Ag. Rabu, 11 September 2019).

Selain itu, pada observasi awal peneliti melihat adanya suatu permasalahan yang cukup unik antara kepala madrasah dan guru-guru di madrasah tersebut. Sehingga pelaksanaan kegiatan belajar mengajar pada madrasah tersebut tidak optimal serta pengawasan kepala madrasah yang kurang optimal mempengaruhi kinerja guru. Guru tidak maksimal dalam menjalankan tugasnya, dan hal ini berdampak pada rendahnya sikap religiusitas peserta didik di sekolah tersebut. (Sumber: Hasil observasi pada. Senin, 9 September 2019).

Sehubungan dengan itu, maka peneliti uraikan fakta-fakta permasalahan sebagai berikut:

a. Masih rendahnya sikap religiusitas peserta didik. Dilihat dari sikap peserta didik yang belum mencerminkan seorang peserta didik madrasah yang bercorak Islam.

b. Pengawasan kepala madrasah belum optimal dan efektif. Hal ini dibuktikan dengan kurangnya dorongan motivasi kerja dari kepala madrasah kepada guru-guru serta kurang maksimal dalam menumbuhkan sikap disiplin dan sikap agamis bagi guru. (Sumber: Hasil Wawancara, Wakamad. Kurikulum MA Darul Ulum Sukaraja. Rabu, 11 September 2019).

c. Kinerja guru yang belum optimal, dilihat dari pelaksanaan pembelajarannya yang berbeda dengan hasil penilaiannya.

Berdasarkan uraian di atas, maka fokus penelitian ini adalah bagaimana manajemen pengawasan kepala madrasah dan kinerja guru dalam meningkatkan religiusitas peserta didik di sekolah menengah atas khusunya di Madrasah Aliyah Darul Ulum Sukaraja Kabupaten Garut. Adapun tujuan penelitian ini adalah mendeskripsikan manajemen pengawasan kepala madrasah dan kinerja guru dalam meningkatkan religiusitas peserta didik di Madrasah Aliyah Darul Ulum Sukaraja Kabupaten Garut.

\section{METODE}

Pendekatan yang digunakan dalam penelitian ini adalah pendekatan kualitatif dengan menggunakan teknik pengumpulan data observasi, wawancara serta teknik dokumenter, sedangkan teknik analisis datanya menggunakan analisis isi (content analysis). Jenis data yang digunakan yaitu 
berupa data sekunder. Penelitian dilakukan dengan mengidentifikasi permasalahan yang terjadi pada kegiatan pembelajaran di MA Darul Ulum Sukaraja Kabupaten Garut, kemudian data dikumpulkan, dianalisis dan disimpulkan sesuai kebutuhan yang mungkin dapat menjadi penyelesaian masalah tersebut berupa strategi pengembangan dengan menggunakan studi kepustakaan.

\section{HASIL DAN PEMBAHASAN}

Sebagaimana halnya perencanaan, pengorganisasian, dan pemberian motivasi, pengawasanpun merupakan salah satu fungsi administrasi dalam menejemen yang penting dalam keseluruhan profesi administrasi.

Proses Pengawasan yang efektif memperlihatkan beberapa karakteristik, diantaranya:

1) Pengawasan hendaknya disesuaikan dengan sifat dan kebutuhan organisasi.

2) Pengawasan hendaknya diarahkan kepada menemukan fakta tentang bagaimana tugastugas dijalankan.

3) Pengawasan hendaknya mengacu kepada tindakan perbaikan.

4) Pengawasan harus bersifat fleksibel.

5) Pengawasan harus bersifat preventif.

6) Sistem pengawasan harus dapat dipahami, jika hendak berarti orang-orang yang terlibat harus memahami apa yang hendak dicapai oleh pengawasan itu dan bagaimana mereka selaku individu dapat menarik manfaat sepenuhnya dari hasilnya.

7) Pengawasan harus bersifat membimbing supaya para pelaksana meningkatkan kemampuan mereka dalam melaksanakan tugas-tugas yang telah diberikan.

8) Pengawasan Pendidikan di Sekolah-Sekolah

Pengawasan pendidikan di sekolah meliputi kegiatan: 1) mengarahkan, membimbing, 2) mendidik, 3) mempertimbangkan dan 4) menilai. Sementara yang menjadi ruang lingkup pengawasan di sekolah ialah pengendalian dan penialain terhadap :

1) Pelaksanaan kurikulum yang meliputi isi, metode pengajaran, penggunaan alat bantu pengajaran dan evaluasi;

2) Pendayagunaan tenaga teknis sekolah dalam rangka terlaksananya proses belajar mengajar yang efektif dan efesiens;

3) Pendayagunaan sarana sekolah sesuai dengan ketentuan dan peraturan perundang-undangan yang berlaku;

4) Ketatausahaan sekolah yang meliputi urusan kepegawaian, keuangan, urusan perkantoran, dan termasuk proyek agar berjalan sesuai dengan ketentuan yang berlaku.

5) Hubungan kerja sekolah dengan instansi pemerintahan dan swasta, dunia usaha dan organisasi masyarakat. 
Adapun temuan yang diperoleh dari penelitian ini yaitu pengawasan kepala madrasah dan kinerja guru dilaksanakan dengan baik dan efektif, sehingga religiusitas peserta didik di Madrasah Aliyah Darul Ulum Sukaraja Kabupaten Garut meningkat. Temuan ini memperkuat aspek pengawasan yang dikemukakan oleh Komariah dan Mulyati (2009) dalam Encu (2012:9), bahwasanya aspek pengawasan yang baik dan efektif itu meliputi: 1) menetapkan standar kinerja, 2) mengukur kinerja, 3) membandingkan unjuk kinerja dengan standar yang telah ditetapkan, 4) mengambil tindakan korektif saat terdeteksi penyimpangan.

Sementara kompetensi kepala madrasah yang baik serta sebagai top manajer di suatu lembaga pendidikan yaitu: 1) mempengaruhi anggota/staff agar menyatu dengan pimpinan/kepala madrasah, 2) memberikan petunjuk kepada anggota/staff, 3) memberikan motivasi agar mencapai unjuk kerja maksimal, 4) melakukan pengendalian dan pengawasan, 5) melakukan evaluasi dan revisi atas hasil unjuk kerja, 6) menciptakan kepuasan bagi para pengikut dalam wujud kesejahteraan. (Suradji 2014: 64-67).

Disamping itu, selain kepala madrasah, komponen lain yang perlu diperhatikan guna menumbuhkan sikap religiusitas peserta didik adalah kinerja guru yang ditunjukan oleh indikatorindikator: (1) kemampuan menyusun rencana pembelajaran, (2) kemampuan melaksanakan pembelajaran, dan (3) kemampuan mengadakan hubungan antar pribadi (Supardi, 2014:40).

Sikap religiusitas peserta didik terlihat dari beberapa aspek, diantaranya: 1) memiliki akhlak yang baik dan meninggalkan akhlak yang buruk, 2) taat, 3) sopan terhadap kedua orang tua, 4) sopan terhadap guru, 5) sopan terhadap teman dan sesama. (Jaelani, 2014:7-10).

Kepala madrasah selain sebagai top manajer juga berfungsi sebagai supervisor di lembaga pendidikan yang ia pimpin, mampu melakukan pengawasan dengan baik dan efektif. Dalam menjalankan tugasnya sebagai seorang pemimpin, kepala sekolah mengelola lembaga pendidikanya dengan melakukan pengendalian dan pengawasan terhadap kinerja bawahannya. Indikator dari pada pengawasan yang dilakukan oleh seorang pemimpin adalah: a) menentukan target dan batasan kerja, b) menentukan tujuan bersama dengan jelas, c) mewujudkan gagasan menjadi kenyataan, d) melakukan pengawasan pada saat realisasi program. (Suradji, 2014:65).

Selanjutnya, kinerja guru dalam menyusun rencana dan program pembelajaran, melaksanakan program pembelajaran dan kemampuan membina hubungan antar pribadi, kemampuan melaksanakan penilaian, kemampuan melaksanakan program pengayaan dan kemampuan melaksanakan program remedial dipengaruhi oleh beberapa factor, salah satu diantaranya adalah pemahaman terhadap kurikulum, khususnya di Indonesia pehamahaman terhadap Kurikulum Tingkat Satuan Pendidikan dan Kurikulum 2013. Semakin tinggi dan baik tingkat pemahaman guru terhadap kurikulum, maka akan semakin meningkatkan kinerja guru. Karenanya pemahaman terhadap kurikulum memberikan kontribusi terhadap peningkatan kinerja guru. 
Selain itu untuk mengetahui kekurangan atau kelemahan kinerja guru, kepala madrasah harus melakukan supervisi, diantaranya adalah dengan memberikan pertolongan melalui bimbingan, pengarahan, pengendalian dan pengawasan terhadap kinerja guru serta mengembangkan kompetensi kerja yang telah dimiliki oleh guru. Beberapa teknik supervisi pengawasan dapat dilakukan oleh kepala madrasah, mulai dari kunjungan kelas, observasi kelas, pertemuan individu atau informal, observasi dokumen, sampai pada rapat dewan guru dalam rangka pengembangan kurikulum dan pengembangan profesional guru yang dilaksanakan melalui observasi. Dari kegiatan supervisi ini, kepala madrasah dapat mengetahui kekurangan atau kelemahan guru baik yang berkaitan dengan kompetensi pribadi, kompetensi pedagogis, kompetensi kemasyarakatan sampai pada kompetensi profesional.

Supervisi berupa pengawasan yang dilakukan oleh kepala madrasah serta pemahaman kurikulum sebagai salah satu faktor peningkatan kinerja guru akan berdampak pada keberhasilan yang dicapai oleh peserta didik. Kepala madrasah bersama-sama dengan guru tidak hanya mendidik, membimbing, mengarahkan dan mengevaluasi peserta didik dari aspek kognitifnya saja, akan tetapi juga aspek afektif dan psikomotorik peserta didik, terlebih untuk tingkat madrasah konten yang diutamakan adalah nilai-nilai keislaman agar tertanam dalam jiwa peserta didik.

\section{KESIMPULAN DAN SARAN}

Pengawasan kepala madrasah dan kinerja guru yang dilaksanakan dengan baik, optimal dan efektif sangat berperan penting dalam meningkatkan religiusitas peserta didik di Madrasah Aliyah Darul Ulum Sukaraja Kabupaten Garut. Pengawasan kepala madrasah dan kinerja guru yang baik dan optimal harus didukung dengan manajemen pengawasan yang efektif. Pengawasan yang baik dan efektif diperoleh dari empat aspek, yaitu: (1) menetapkan standar kinerja, 2) mengukur kinerja, 3) membandingkan unjuk kinerja dengan standar yang telah ditetapkan, 4) mengambil tindakan korektif saat terdeteksi penyimpangan. Sementara indikator dari pada pengawasan yang dilakukan oleh seorang pemimpin dalam hal ini adalah kepala madrasah yaitu: a) menentukan target dan batasan kerja, b) menentukan tujuan bersama dengan jelas, c) mewujudkan gagasan menjadi kenyataan, d) melakukan pengawasan pada saat realisasi program.

Adapun saran untuk penelitian lebih lanjut, mengingat terdapat beberapa temuan penting pada penelitian serta keterbatasan dalam penelitian ini maka diharapkan pada masa yang akan datang berbagai pihak dapat meneliti lebih lanjut faktor lain (epsilon) dari variabel-variabel penelitian ini. Penelitian lanjutan lain yang disarankan diantaranya dikarenakan para guru berasal dari latar belakang pendidikan yang berbeda maka dipandang perlu untuk melakukan penelitian lebih lanjut terhadap pengaruh latar belakang pendidikan terhadap kepemimpina kepala madrasah kinerja guru serta sikap religiusitas peserta didik.

\section{DAFTAR PUSTAKA}

\section{Buku :}


Encu, A. (2014). Manajemen dan Kepemimpinan Kepala Madrasah. Bandung: Pustaka Billah. Hasibuan, M. (2016). Manajemen Sumber Daya Manusia. Jakarta: PT. Bumi Aksara.

Marno, \& Supriyatno, T. (2008). Manajemen dan Kepemimpinan Pendidikan Islam. Bandung: PT Refika Aditama.

Mulyasa, E. (2013). Menjadi Kepala Madrasah Profesional. Bandung: PT Remaja Rosdakarya.

Mulyasa, E. (2015). Manajemen dan Kepemimpinan Kepala Madrasah. Jakarta: PT Bumi Aksara.

Priansa, D. J. (2014). Kinerja dan profesionalisme Guru. Bandung: CV Alfabeta.

Rahmat, A. (2013). Manajemen Pendidikan Islam. Gorontalo: Ideas Publishing.

Sagala, S. (2013). Kemampuan Profesional Guru dan Tenaga Kependidikan. Bandung: Alfabeta.

Supardi. (2014). Kinerja Guru. Jakarta: Rajagrafindo Persada.

Suradji. G (2014). Ilmu dan Seni Kepemimpinan. Jakarta: Reka Cipta.

Syah, M. (2013). Psikologi Pendidikan. Bandung: PT Remaja Rosdakarya.

Wahyudi. (2012). Kepemimpinan Kepala Madrasah (Dalam Organisasi Pembelajaran). Bandung: Alfabeta

Rusyan, T., \& Wasmin. (2008). Etos Kerja (Dalam Meningkatkan Produktivitas Kinerja Guru). Jakarta: PT Intimedia Ciptanusantara.

Saefullah. (2014). Manajemen Pendidikan Islam. Bandung: PT Pustaka setia.

Sudjana, N. (2017). Penilaian Hasil Proses Belajar Mengajar. Bandung: PT Remaja Rosdakarya.

Tafsir, A. (2014). Ilmu Pendidikan Dalam Prespektif Islam. Bandung: PT Remaja Rosdakarya.

Wahyudi. (2012). Kemimpinan Kepala Sekolah Dalam Organisasi Pembelajar (Learning Organization). Bandung: Alfabeta.

\section{Jurnal :}

Hamdan, Y. (2018). Pengaruh Kepemimpinan Kepala Madrasah dan Kohesivitas Guru Terhadap Kinerja Guru Dalam Mewujudkan Hasil Belajar Peserta Didik. Khazanah Akademia. Garut: Universitas Garut.

Jaelani, A. (2014). Pendidikan Karakter Anak Perspektif Syaikh Umar bin Achmad Baradja Dalam Kitab Al-Akhlak Al-Baniin Jilid I. Garut: Uniga.

Mustahidah, A. (2013). Pengaruh Kepemimpinan Kepala Sekolah Terhadap Manajemen Pembelajaran Untuk Meningkatkan Hasil Belajar Peserta didik. Garut: Uniga. 